\title{
The Impact of Economic Factors on Hospital Performance from The Managers' Perspective: An Applied Study of Security Forces Hospital, Makkah
}

\author{
Dr. Omar Z. Alsharqi \\ Department of Health Services and Hospitals \\ Faculty of Economics and Administration - King Abdulaziz \\ University - Jeddah- Saudi Arabia
}

Amal Mohsen Al-Hakami

Faculty of Economics and Administration

King Abdulaziz University

Jeddah- Saudi Arabia 


\section{Acknowledgment}

First, I am grateful to God for the good health and well-being that was bestowed upon me in order to complete this research.

I wish to express my sincere appreciation to my respectable mother and my sister for encouraging and supporting me spiritually throughout writing this research and for giving me inspiration in all the stages of my life in general. Also, I wish to express my sincere thanks to my supervisor Dr. Omar Alsharqi for his patience, motivation, and immense knowledge. His guidance had helped me on writing this research. I could not have imagined having better advisor and mentor for my research study.

I would like to acknowledge My Director, Colonel. Dr. Khalid Hassan Alzahrani for his continuous support, then and now.

I also extend my gratitude to Ms. Rola Almalki, for her continuous support and sincere help in revising the thesis.

Last but not the least, I would like to thank all who accepted to participate in the survey, which had supported my work in the best possible way and helped me to get the best quality of results.

To all these wonderful, professional and inspiring people, thank you! May God bless you 


\section{Abstract}

During the last decade, most of the countries faced a lot of pressures with increasing in the public expectations and demands for health care. Where countries around the world redesigned and restructured their strategies and policies to provide good healthcare. This study aimed to identify the effect of economic factors (budget, and resources) on healthcare performance. To achieve the aim of this study, the researcher adopted the descriptive analysis design. The population of the study was the workers in administration positions in the Security Forces Hospital, in Makkah city, Saudi Arabia during 2018. To collect the needed data, the questionnaire is used as a tool for analyzing data. The response rate was 94.2\%. Data were analyzed by using SPSS. Four hypotheses were tested based on data collected. The results of the Chi square analysis demonstrated that significant relation was found between organization performance and budget, human resources, material resources, and resources allocation. The recommendations made from this study are the following: the organization should work hardly on the budgetary strategies and process. provide the staff with training opportunities to increase the quality of service. provide the facility with all necessary equipment to increase the quality of service.And provide the stockholder and administrator with the appropriate training on the new methods and techniques of managing resources and how to allocate them. 


\section{|لمدض}

خلال العقد الماضي، واجهت معظم البلدان الكثير من الضغوط مع زيادة توقعات الجمهور ومطالبته بالر عاية الصحية. حيث قامت الدول من جميع أنحاء العالم بإعادة تصميم و إعادة هيكلة استراتيجياتها وسياساتها لتوفير الرعاية الصحية الجيدة. هدفت هذه الدراسة إلى تحديد تأثير العو امل الاقتصادية (الميزانية والموارد) على مستوى أداء الرعاية الصحية في المستشفيات من . من وجهة نظر المدراء. لتحقيق هدف هذه الدراسة، اعتمدت الباحثة المنهج التحليل الوصفي. تكون مجتمع الدراسة من العاملين في المناصب الإدارية في مستشفى قوى الأمن، في مدينة مكة المكرمة، المملكة العربية السعودية خلال عام 1 1 •r. لجمع البيانات المطلوبة، تم استخدام الاستبيان كأداة لتحليل البيانات. كان معدل الاستجابة ب. ؟ ٪ ٪. تم تحليل البيانات باستخدام SPSS. تم اختبار أربع فرضيات بناءً على البيانات التي تم جمعها. أظهرت نتائج تحليل مربع كاي أن هنالك علاقة بين أداء المنظمة والميز انية والموارد البشرية و الموارد المادية وتخصيص الموارد. تتمثل التوصيات المقدمة من هذه الدر اسة فيما يلي: يجب على المنظمة العمل على استر اتيجيات الميز انية. تزويد الموظفين بفرص التدريب لزيادة جودة الخدمة. تزويد المرفق بجميع المعدات اللازمة لزيادة جودة الخدمة. وتزويد المسئولين بالتدريب المناسب على الأساليب و التقنيات الجديدة لإدارة الموارد وكيفية تخصيصها. 


\section{Chapter One}

\section{Preface}

This chapter introduces the research background, research problem and significance of the study. Moreover; this chapter presents objectives, methodology, research model, hypotheses and research structure.

\section{Background}

During the last few decades, healthcare services in the Kingdom of Saudi Arabia (KSA) extremely developed especially in two places access and quality (Almutairi and Moussa, 2014). The World Health Organization (WHO) estimated the Saudi health care system in 26th position among 190 of the world's health systems, where its higher position than Canada (30), Australia (32), New Zealand (41), the United Arab Emirates (27), Qatar ( $\varepsilon \varepsilon$ )and Kuwait (45) (Almalki et al, 2011).Between 1970 and 2009, the number of hospitals rose from 74 to 415 , and the number of beds rose from 9,039 to 58,126 . The Saudi government is prioritizing health care services for Saudisand expatriates working in government (Walston S et al, 2008; Almutairi and Moussa, 2014).During 2009 11\% of the Kingdom's budget equal 52.3 billion SAR ( $\$ 14$ billion) was assigned to develop health care system (Almutairi and Moussa, 2014). There are 3 main sectors responsible for providing health services the $\mathrm{MOH}$, other governmental institutions, and the private sector, where the $\mathrm{MOH}$ is the main provider $(62 \%)$ of health services for inpatient as well as it is the responsible and financer of health care services for the entire population, it supervises 244 hospitals with 33,277 beds and 2,037 primary health care (PHC) centers distributed on 20 health directorates among 13 regions (Walston S et al, 2008; Almutairi and Moussa, 2014). The second main healthcare provider is the 
Medical Services Department of the Ministry of Defense and Aviation, with over 4000 hospital beds and employs over 2400 physicians. The last main provider is private sector which showed rapid growth during the last 40 years and served expatriates working in private as well as Saudi citizens (Walston S et al, 2008; Almutairi and Moussa, 2014).In spite of these improvements in healthcare system, still there are many challenges faced the Saudi healthcare system, these challenges presented as "lack of Saudi health professionals, the multiple roles of $\mathrm{MOH}$, limited financial resources, changing patterns of disease, high demand due to free services, an absence of a national crisis management policy, poor accessibility to some healthcare facilities, shortage of a national health information system, and the underutilization of the potential of electronic health strategies", which need to adopt new strategies and policies by the Saudi Ministry of Health $(\mathrm{MOH})$ as well as effective collaboration with other sectors (Almalki et al, 2011).This information of Saudi Arabia healthcare system challenges agreed with other studies from different countries such as the study of Keele, UK and (Hornby and Forte, 2003; Basu et al, 2012).

During the last decade, most of the countries faced a lot of pressures with increasing in the public expectations and demands for health care. Where countries around the world redesigned and restructured their strategies and policies to provide good healthcare, particularly after the global economic recession started in 2007. They started to use more radical solutions such as gathering all available resources and increasing the private sector participation in providing healthcare services to reduce government debt (Hornby and Forte, 2003; Basu et al, 2012). 
The anatomy of mutual influence economic growth and healthcare services is a very challenging subject in the health economics literature. Where several studies focused on the effects of health on economic growth, others focused on the effects of economic growth on healthcare changes(López - Casasnovas and Soley - Bori, 2014).

Budgeting traditionally plays a great role as a center point in the managing and controlling organizations' systems through a tool called budget. (Libby T and Lindsay RM, 2009; Iacob and Constantin, 2015) However, in the last few years, a lot of studies and researchers put traditional annual budgeting system under criticism, where a lot of evidence confirmed that old budget method is inflexible, time-consuming for determining the relation between the purpose and outcomes, and slow in detecting problems and couldn't deal with surprising and unpredictable events. (Libby and Lindsay, 2009; Iacob and Constantin, 2015). It is a really complex process particularly in the healthcare sector, where healthcare program is formed by the decision made during putting the budget. This means that there is a great need to recognize how decisionmakers view healthcare systems to recognize their policy towards healthcare system (White J, 2013).In last few years a lot of healthcare organization starts to use both the old budget method and the new methods such as internal budgeting and performance budgeting (Macinati and Rizzo, 2014; Haas, and Gajdošová, 2016).

Determining the ideal distribution of resources to develop health is a great challenge to policymakers and legislators (Baghbanian et al, 2011). So, despite some reluctance responsibility of the financial sense has been allocated to clinicians, this could be explained by the fact that they are the 
key factor of source consumption and management (Baghbanian et al, 2011; Macinati and Rizzo, 2014).

The World Health Organization (WHO) report (2000), identified several economic factors affecting health care systems: human resources, physical capital and consumables. (The World Health Organization report,2000).With the increasing of health expenditures around the world, Human resources considered as the main factor of any health care system, where several studies associated between the shortage of health workers and bad outcomes (Danon-Hersch, and Paccaud, 2005).

The availability of resources influences the quality of healthcare services, as well as the quality of high-quality services need high-quality inputs, where working with low-quality material or old equipment would take more time, raise job's stress and reduce workers' productivity (quality and quantity). As an example, obtaining a patient's vital signs needs around 30 minutes using the old methods, however, it would be accomplished in less than one minute through the use of new equipment's. Another example, if the DC Shock machine in the operation room is not working, the staff would stress over what may happen if a patient actually needed it. Administrators and policy-makers defined financial resources as "the major element influencing the quality of healthcare"; where financial resources influenced the quality of service provided by organizations (Mosadeghrad, 2014).

\section{Research Problem}

It is evident that health sector plays an integral role in both developed and developing economies. However, staff at hospital in the Kingdom of Saudi Arabia faces a huge challenge especially in light of 
seriously seeking to solve health service problem that compounded with the steady increase in the number of population. Economic development plans were developed through the investment of human and material resources to support economic structures.

Unfortunately, there is a shortage of the research investigated in the influence of economic factors such as budgets and resources (human and financial resources) on the quality of patient services. As I am working in health sector, I choose to do this study to detect these problems and bridge the gap in health sector. In fact, this study will shed the light on economic factor that is considered the most important to health care sector at current time.

\section{Research Objectives}

The general objective of this study is to identify the effect of economic factors on hospital performance. This study will investigate the two economics factors which are budget, resources. So, the Specific objectives are:

1. To identify the relationship between budget and hospital performance.

2. To identify the relationship between resources and hospital performance.

\section{Research Importance}

The importance of the study is discovered in the following point:

1. This study will address the role of the budget of healthcare organizations, and resources to disclose their impact on achieving a good hospital performance. 
2. Help Decision-makers at government healthcare organization to know economic aspects and their impact on hospital performance to provide good health care performance.

3. Poorly budget and inadequate resources have negative influence on the hospital workers' performance and the entire health system.

4. Make suggestions and recommendations to benefit of researchers in the field of this study as well as established for further studies on this subject which combines between economic factors and health care.

\section{Research Variables}

1. Dependent variable: Hospital performance.

2. Independent variables: Economic factors (Budget and Resources).

\section{Research Hypothesis}

1. There is a significant statistic relationship between budget and hospital performance.

2. There is a significant statistic relationship between human resources and hospital performance.

3. There is a significant statistic relationship between material resources and hospital performance.

4. There is a significant statistic relationship between resources allocation and hospital performance.

\section{Definition of the Study Terminology}

Resource: "The inputs required to make health systems work (human and financial resources, drugs, supplies and equipment, and infrastructure)". (World Health Organization: World Health Systems Strengthening Glossary, 2017) 
Budgeting:" is a short-term economic plan that is provided the resources allocated and used, expressed in monetary terms" (Iacob C and Constantin C, 2015).

Hospital performance: "doing the right thing, at the right time, in the right way - and having the best possible results." (State of new jersey, department of health, 2018).

\section{Methodology:}

This study was conducted using descriptive analytical design. Quantitative data was collected using questionnaire as a suitable tool for collecting quantitative data. This method is the appropriate method to conduct this research, as it can be used to conduct and explain the relation between hospital performance and budget, human resources, material resources, and resources allocation. The design of the questionnaires was depended on existing instruments used before to collect data in previous studies and evaluated by number of academic experts. The research population consists of all the workers in administration positions in the Security Forces Hospital, Makkah city, Saudi Arabia during 2018., with total number 86. All workers in administration positions were invited by researcher to participate in the study. More details concerning this part of the research methodology are found in chapter three.

\section{Research Model}

The research variables are illustrated in the following diagram:

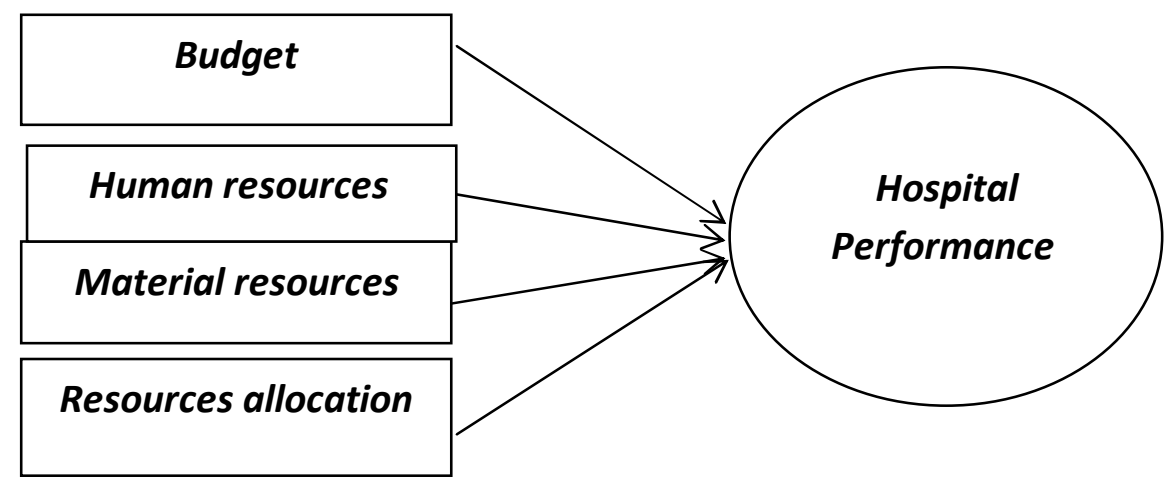




\section{Study Structure:}

The research structured in the following format:

Chapter 1, Introduction: The first chapter introduces the research background, research problem and significance of the study. Moreover; this chapter presents objectives, methodology, research model, hypotheses and research structure.

Chapter 2, Previous Studies: This chapter presents the previous studies and literature review that provides the rational for conducting the current study to investigate the specified research problem.

Chapter 3, Research Methodology: This chapter presents the research methodology including data collection method and sampling, and instruments. As well as, this chapter presents the construct validity and reliability of the pilot and the main study.

Chapter 4, Data Results Analysis and Discussion: This chapter presents data results analysis, and discussion of the findings of the study.

Chapter 5, Summary, Conclusion and Recommendations: This chapter presents final part of the study that includes conclusion of the findings, following by the recommendations for future research directions. 


\section{Chapter Two: Literature Review\& Previous Studies}

\section{Preface:}

This chapter contains information about the impact of economic factors (budget, human resources, material resources, and resources allocation) on the hospital performance based on previous studies.

\section{Budget:}

The management control systems (MCS) defined as"all devices and systems that businesses use to ensure that the behaviors and decisions of their employees are consistent with the organization's objectives and strategies" (King et al,2010).

Budget is considered as one of the main MCS due to the fact that it can affect the behaviors and decisions of employees by converting the business's objectives into plans for action, communicating the objectives, and providing a standard to assess performance(King et al,2010).

Ideally, the annual budgeting process put the performance agenda for the year ahead. But, healthcare budgets have usually estimated the income and expenditure (Bynre, 2007). Where globally, budgets are sensitive to political influence whereby financial control can be reduced by the personal preferences of 'well-connected' individuals or groups with vested interests. (Bynre, 2007).Budgets can ease the required delegation of both managerial responsibilities and expenditure consumption. Also, it can improve the speed of decision-making if there is no need for approval from a higher-level manager (Bynre, 2007).

\section{Recourses}

Human Resources (HR) are "the lifeblood of an organization". Even with the use of technology in modern business management, human 
resources are still relevant and most adaptive resources of the organization. Where human resources have the ability and power for decision-making power. Also, HR links other resources in the right mix to develop appropriate strategies for the achievements of the desired objectives of the organization (Isaiah,2012).

The management of HR is complicated and problematic, where employees have needs, aspirations, motivations, desires, and interests affect their behavior at work, as well as their objectives, are sometimes against the organization objectives of the enterprise (Isaiah,2012).In order to solve these issues there is the need for HR practitioners to have new kinds of technical knowledge, skills and abilities to be more flexible and willing to deal with the ever-accelerating pace and often unpredictable changes in the global workplace (Maryhofer and Brewster, 2005).

Resource allocation refers to "the distribution of resources, particularly finance from the central level to the peripheral levels". It refers also to "the distribution of resources among competing groups of people, organizations, ministries, and programs". Resource allocation has two equal faces economic and moral challenge (distributive justice)(Shamu,2013). Gugushvilli (2007) reported that resource allocation is a difficult exercise. In order to solve this difficulty, theoretical studies included three dimensions of resource allocation; " cost-effectiveness analysis of treatments, use of quality-adjusted life years and needs-based resource allocation which focused on health needs "(Gugushvilli,2007). Resource allocation and budgeting are two sides of the same coin (Green 1992). When resource allocation is generally associated with the broad allocation of overall financial resources, budgeting refers specifically to the 
detailed plan of how funds are to be used. There are several levels of resource allocation; national level, ministry level, and facilities level. Also, resource allocation has different levels of decision making: macro level involves government policymakers and micro level involves hospital administrators (Shamu,2013).To increase the quality of health outcomes, there is a need for mechanisms fairly address all the population and regions' health needs. McIntyre and Anselmi (2012), reported that the most common indicators of need are;

population size.

demographic composition.

levels of ill health.

socio-economic status(McIntyre and Anselmi ,2012).

\section{Health care performance}

In the last few decades, there was increasing in the demands for high quality health care. This could be due for several reasons: the global demographic changes, aging, and higher expectations towards health systems performance (Kalinichenko et al,2013).

On the other hand, with the continued growth of health care expenditures, it is estimated that the majority of OECD countries will spend about 20\% of GDP on health care by 2050 (Drouin et al., 2008). These trends motivated both researchers and policymakers to search for more innovative solutions for the appropriate use of the scarce resources in order to guarantee that the changing needs for health care are met and health systems work with the most efficiently and effectively (Kalinichenko et al,2013). 


\section{Previous studies:}

A Study conducted by Byrne under the title "The usefulness of budgets in the Healthcare sector"2007. The study aims to identify the role of the budget in the development of health care sectors. The study followed the analytical descriptive method, based on many previous studies. Results showed that budgets based on multi-year activities for budget reform could be used, starting from the bottom up, with departments, individual services and resources based on evidence-base, assessment and reward using a more balanced approach and a set of performance indicators to improve performance in health care sectors. Recommendations made by this study are: Improving communication between different administration levels and healthcare organizations, in order to restructure and repair budgetary which consists of the use of multi-annual, real-time and bottom-up activity (Byrne, 2007).

A Study conducted by Libby and Lindsay under the title "Beyond budgeting or budgeting reconsidered? A survey of North-American budgeting practice"2009. They used a web-based survey toselect the data from 2583 CMA Canada members and 13,712 IMA members. The study aims to show the results of two surveys of mid- to large-sized NorthAmerican organizations, to update the literature on budgeting, to collect evidence to evaluate the criticisms and to determine the patterns in budgeting practice. They found that most of the companies use budgets for control, and if there are problems with budgets, they modify their use instead of completely withdrew. Recommendations made by this study are: the budgeting procedures should be connected to strategy implementation, 
as well as firms should be modified their budgets processes than give up from using (Libby and Lindsay, 2009).

A Study conducted by King and et al under the title "Budgeting practices and performance in small healthcare businesses"2010. They distributed and collected written survey from 988 members of the Australian Association of Practice Managers (AAPM). The study aims to detect the association between contextual factors (identified from contingency-based research the adoption and extent of use of budgets), and business performance in the Australian primary healthcare setting. They collect of 144 responses from the members of the Australian Association of Practice Managers (AAPM). The findings showed that factors determined by "contingency-based research" are good indicators for business's budgeting practices, also they reported a positive association between budgeting practice and performance, and they linked written budgets and positive performance, Recommendation made by this study is: further research to detect the reliability and accuracy of the suggested contingency factor model as an indicator of the use of budget versus scope of use in settings regardless of the primary healthcare sector (King R et al, 2010).

A Study conducted by Hornby and Forte under the title "Human Resource Indicators and Health Service Performance"2003. The study followed the analytical descriptive method, based on many previous studies. The study aims to investigate the use of human resource indicators (HRI) to support administration initiatives to increase the efficacy of health service. They did that in two steps, first, they check the role of management indicators, second, they concentrate on HRI measurements (the indicators, 
their interpretation and presentation). They conclude that there is a necessity to work on the ways to use these indicators in health services by linking them with management activities and purpose to increase their values. Recommendation made by this study is: to make the improvement of indicators meaningful, it must be connected to management growth (Hornby and Forte, 2003).

A study conducted by Harris et al under the title ""Human resource management and performance in healthcare organizations" 2007.The authors aimed to review and compare the evidence from a range of reviews concerned with the links between human resource management (HRM), and performance. The authors examined recent reviews of the human resource management and performance literature and previously unpublished review. The authors reported that there are relationships between a range of HRM practices, policies systems, and performance. There is little research exploring the link between HRM and performance in the health sector. The authors concluded that increasing autonomy for healthcare organizations in the UK, i.e. Foundation Trusts, could offer increased opportunity for locally tailored HR systems and practices (Harris et al, 2007).

A Study conducted by Baghbanian et al under the title "Resource allocation and economic evaluation in Australia's healthcare system"2011. A purposive sample of 91 Australian healthcare decision-makers was invited through email to fill online questionnaire. The study aims to detect the dimensions and diversities of economic evaluations that healthcare decision-makers use or not. They invite a group of Australian healthcare decision-makers directly through email to fill an online questionnaire 
derived from the EUROMET 2004 survey. The results showed that the majority of the 91 participants engaged in financial resource distributions, where they reported that their decisions rely on "patient needs, interference efficacy, cost of interventions which means total budgetary effect, and policy advices" particularly the evidence from cost-effectiveness. They reported 3 main barriers prevent them from the utilizing of economic evaluation "timing, ethical issues and lack of knowledge". They conclude that decision-makers appreciate health economic evaluations evidence as an important method to use in real life in providing information help them in taking decisions, even it is not yet a central to many decisions. Recommendations made by this study are further studies to provide more evidence and placing economic evaluation into context to be useful in reallife policy decisions (Baghbanian et al, 2011).

A study conducted by Ragupathi under the title "The Financial and Human Resource Management Strategies to Develop the Organization" 2013. The author concentrated on developing a new system serve multiple purposes (strengthening, investment in human resource and develop a model which can quantify). It is mainly for determining new dimensions beyond financial management (FM) and Human Resource Management (HRM)). In this day money spends on acquiring, managing of human resource as it is considering as an investment, not like before as an expenditure. Human Resource is an asset to the organization, appreciate with time, only when provided predominant input. Even that the commitment from the top management in investment in the human resource development is an improvement, still this proposal is questioned and undergo to the condition of the business (Ragupathi,2013). 
A Study conducted by Smith et al under the title "High performance in healthcare priority setting and resource allocation: A literature- and case study-based framework in the Canadian context" 2016. They conduct indepth case studies of six Canadian healthcare organizations with 62 managers. They use site observations and document review to assist researchers in interpreting the interview data. The study aims to provide leaders with instructions to develop priority setting and resource allocation (PSRA) practice. They included the leaders of six Canadian healthcare organizations, they detect their understanding of the meaning of high performance in PSRA and the factors affected it. Data were collected through two ways, first, individual and group interviews were conducted with 62 managers and Board members. Second, reviewing documents and running site observations to help in explaining the interview data. They create a framework of four domains (structures, processes, attitudes and behaviors, and outcomes) with 19 elements helped in determining areas of improvement. Recommendation made by this study is to generalize the new framework to be used in Canada and other countries (Smith et al, 2016). 


\section{Chapter Three: Methodology}

\section{Preface}

This chapter presented the research design, study area, population of the study, sample size sampling technique, data source, data collection instruments data analysis and presentation.

\section{Study Design}

The method applied in this study is a descriptive analysis method, which define as "The transformation of raw data into a form that will make them easy to understand and interpret; rearranging, ordering, and manipulating data to generate descriptive information" (Zikmund, 2003). This design is suitable for the study, where the researcher is described all the factors related to the study variables (Budget, resources and hospital performance) and detect if there is a relation between them.

\section{Study Area}

This study was conducted in Security Forces Hospital located in Makkah Al-Mukarrama, Al-Awali Region around $10 \mathrm{Km}$ from The Holy Mosque toward east. SFHM started in the last Quarter of 2013 and it is providing high quality health care services to Ministry of Interior employees and their dependents. The hospital is upgrading gradually toward the excellence with capacity around 200 beds.

\section{Study Population and Sample Size:}

Study population is defined as "an entire group about which some information is required to be ascertained", where study population could be defined by "geographic location, age, sex, with additional definitions of attributes and variables such as occupation, religion and ethnic group" (Banerjee et al, 2010). After reviewing the number of workers in 
administration positions in the Security Forces Hospital (the estimated number is 86(directors, heads of medical departments, heads of administrative departments and head nurses).

Sample size is defined as: "the sample chosen from the study population"(Banerjee et al, 2010). Sample size will be (86) including directors (25), heads of medical departments (20), heads of administrative departments (19) and head nurses (22).The reason for choosing this sample is due to the fact that this study will focus on economic factors (budget and resources) and their influence on performance, these kinds of information can't be obtained from workers, they can be obtained only from people in leader and administrative position.

\section{Sampling Technique}

The researcher chose the convenience sample, where all the 86 directors and heads of departments in the Security Forces Hospital during the study period will be include in the study. The convenience sample: A statistical method of drawing representative data by selecting people because of the ease of their volunteering or selecting units because of their availability or easy access.

\section{Data Collection Tool (Instrument)}

- Questionnaire: Self-administered.

- The questionnaire has 2 parts:

- Hospital care performance.

- Economic factors (Budget and Resource).

Data collection will be conducted at December 2017. Hand delivering of the questionnaires by researcher to the respondents at the break time and collecting them later at the same day. 


\section{Validity and Reliability}

This section presents the external and Internal validity and reliability of study questionnaire.

\section{External validity:}

To verify the external validity of the questionnaire, it was presented to three faculty members from the from faculty of economic and administration to benefit from their knowledge base, which developed the scale and made it more objective.

\section{Internal Validity:}

To verify the internal validity of the questionnaire, the researcher calculated the correlation coefficients between each statement of the domains and the total score of the domain itself. The results in Table (1) show that each factor is related to its overall variable in terms of significance. The 12 factors associated with the overall budget variable were associated significantly ( $\mathrm{p}<0.0001)$, the 9 factors associated with the overall human resources variable were associated significantly ( $\mathrm{p}<0.0001)$, The 10 factors associated with the overall material resources variable were associated significantly $(\mathrm{p}<0.0001)$, the 11 factors associated with the overall resources allocation variable were associated significantly ( $p$ $<0.0001$ ), and the 11 factors associated with the overall hospital performance variable were associated significantly $(\mathrm{p}<0.0001)$. 
Table (3-1) Correlation \& Internal Validity

\begin{tabular}{|c|c|c|}
\hline \multicolumn{3}{|c|}{$\begin{array}{l}\text { 3-1-1 Correlation coefficient between each statement of the "budget" and the } \\
\text { total score of the domain }\end{array}$} \\
\hline Statements & $\begin{array}{c}\text { Pearson } \\
\text { correlation } \\
\text { coefficient }\end{array}$ & P value \\
\hline $\begin{array}{l}\text { 1. Management participate in assessing annual } \\
\text { budget needs }\end{array}$ & $.716^{* * *}$ & $0.000 *$ \\
\hline $\begin{array}{l}\text { 2. There are models for presenting the annual } \\
\text { estimated management requirement }\end{array}$ & $.665^{* *}$ & $0.000 *$ \\
\hline $\begin{array}{l}\text { 3. Estimates of needs are decided by departments } \\
\text { taken in consideration when preparing the } \\
\text { budget }\end{array}$ & $.774^{* * *}$ & $0.000 *$ \\
\hline $\begin{array}{l}\text { 4. Are you notified of the amounts approved for } \\
\text { you in the annual budget? }\end{array}$ & $.764^{* * *}$ & $0.000 *$ \\
\hline $\begin{array}{l}\text { 5. The amounts approved in the budget help to } \\
\text { provide services efficiently. }\end{array}$ & $.753^{* * *}$ & $0.000 *$ \\
\hline $\begin{array}{l}\text { 6. The budget manages the resolution of } \\
\text { emergency crises that may occur during the } \\
\text { financial year and beyond the estimates. }\end{array}$ & $.741^{* * *}$ & 0.001* \\
\hline $\begin{array}{l}\text { 7. There is flexibility in budget management to } \\
\text { adjust the estimation errors. }\end{array}$ & $.709^{* * *}$ & $0.000 *$ \\
\hline $\begin{array}{l}\text { 8. The amounts allocated to the departments } \\
\text { divided according to actual need. }\end{array}$ & $.678^{* * *}$ & $0.000 *$ \\
\hline $\begin{array}{l}\text { 9. The approved amounts to be used in what they } \\
\text { actually planned. }\end{array}$ & $.673^{* *}$ & 0.000* \\
\hline $\begin{array}{l}\text { 10. During the implementation stages of the budget, } \\
\text { there is a monitor the plans that are prepared } \\
\text { by you in partnership with others (budget, } \\
\text { follow-up, planning). }\end{array}$ & $.693^{* * *}$ & $0.000 *$ \\
\hline $\begin{array}{l}\text { 11. The comparison between what was approved } \\
\text { and what was requested done at the end of the } \\
\text { financial year, and specifying the deficiencies } \\
\text { and insufficiency. }\end{array}$ & $.756^{* *}$ & $0.000 *$ \\
\hline $\begin{array}{l}\text { 12. The board has one or more members with } \\
\text { professional-level financial expertise. }\end{array}$ & $.540^{* *}$ & $0.000 *$ \\
\hline
\end{tabular}




\begin{tabular}{|c|c|c|}
\hline $\begin{array}{l}\text { Correlation coefficient between each statement of } \\
\text { and the total score of the domain }\end{array}$ & 'h & 1 \\
\hline Statements & $\begin{array}{c}\text { Pearson } \\
\text { correlation } \\
\text { coefficient }\end{array}$ & SIG \\
\hline $\begin{array}{l}\text { 1. Organization's HR executives are fully aware of } \\
\text { the business needs and strategies. }\end{array}$ & $.670^{* * *}$ & $0.000 *$ \\
\hline $\begin{array}{l}\text { 2. All major jobs are subject to formal job } \\
\text { analysis. }\end{array}$ & $.773^{* *}$ & $0.000 *$ \\
\hline $\begin{array}{l}\text { 3. The organization has a formal policy of career } \\
\text { planning and development. }\end{array}$ & $.752^{* * *}$ & $0.000 *$ \\
\hline $\begin{array}{l}\text { 4. The organization follows a formal procedure of } \\
\text { potential appraisal. }\end{array}$ & $.775^{* *}$ & $0.000 *$ \\
\hline $\begin{array}{l}\text { 5. The organization has a structured policy for } \\
\text { management of attrition and turnover. }\end{array}$ & $.736^{* *}$ & $0.000 *$ \\
\hline $\begin{array}{l}\text { 6. The organization encourages employees to } \\
\text { suggest product/process improvement. }\end{array}$ & $.751^{* * *}$ & 0.001* \\
\hline $\begin{array}{l}\text { 7. The organization has provision for employee } \\
\text { recognition programs and awards. }\end{array}$ & $.772^{* * *}$ & $0.000 *$ \\
\hline $\begin{array}{l}\text { The organization has been managing change by } \\
\text { integrating the HR issues with the business strategies } \\
\text { and the strategic change process. }\end{array}$ & .836 ** & 0.000* \\
\hline There is enough man power in the department. & $.584^{* * *}$ & $0.000 *$ \\
\hline
\end{tabular}

\begin{tabular}{|c|c|c|}
\hline $\begin{array}{l}\text { 3-1-3 Correlation coefficient between each statement of } \\
\text { and the total score of the domain }\end{array}$ & materia & rses " \\
\hline Statements & $\begin{array}{c}\text { Pearson } \\
\text { correlation } \\
\text { coefficient }\end{array}$ & SIG \\
\hline $\begin{array}{l}\text { 10. There is need assessment for material resources in } \\
\text { my organization. }\end{array}$ & $.535^{* *}$ & $0.000 *$ \\
\hline $\begin{array}{l}\text { 11. There is Planning of purchasing material resources } \\
\text { in my section. }\end{array}$ & $.580^{* * *}$ & 0.000* \\
\hline $\begin{array}{l}\text { 12. There is a quick and reliable selection for the } \\
\text { suppliers. }\end{array}$ & $.722^{* * *}$ & $0.000 *$ \\
\hline $\begin{array}{l}\text { 13. Sufficient permanent stores are built in the } \\
\text { organization. }\end{array}$ & $.666^{* *}$ & 0.000* \\
\hline 14. Sufficient material resources were stored. & $.674^{* *}$ & $0.000 *$ \\
\hline
\end{tabular}




\begin{tabular}{|l|l|c|c|}
\hline $\begin{array}{l}\text { 15. The hospital follows WHO recommendation in } \\
\text { storing equipment. }\end{array}$ & $.598^{* *}$ & $\mathbf{0 . 0 0 1 *}$ \\
\hline $\begin{array}{l}\text { 16. Stores are secured enough. } \\
\text { 17. The material resource in my office have audited } \\
\text { annually. }\end{array}$ & $.669^{* * *}$ & $\mathbf{0 . 0 0 0 ^ { * }}$ \\
\hline $\begin{array}{l}\text { 18. Follow up of material resource is done quarterly, } \\
\text { semiannually and annually by property } \\
\text { administration department. }\end{array}$ & $\mathbf{0 . 0 0 0 ^ { * }}$ \\
\hline $\begin{array}{l}\text { 19. Identify the level of damage and depreciation of } \\
\text { each material. }\end{array}$ & $\mathbf{. 7 0 0 ^ { * * }}$ & $\mathbf{0 . 0 0 0 ^ { * }}$ \\
\hline
\end{tabular}

\begin{tabular}{|c|c|c|}
\hline \multicolumn{3}{|c|}{$\begin{array}{l}\text { 3-1-4 Correlation coefficient between each statement of the "recourses allocation" } \\
\text { and the total score of the domain }\end{array}$} \\
\hline Statements & $\begin{array}{c}\text { Pearson } \\
\text { correlation } \\
\text { coefficient }\end{array}$ & SIG \\
\hline Allocate adequate budget for maintenance. & $.709^{* *}$ & $0.000 *$ \\
\hline 21. Use of qualified personnel for maintenance. & $.721^{* * *}$ & $0.000 *$ \\
\hline 22. $\quad$ Redistribution of the maintained materials. & $.753^{* *}$ & $0.000 *$ \\
\hline $\begin{array}{l}\text { 23. Regular and efficient Identification of obsolete } \\
\text { materials. }\end{array}$ & $.806^{* *}$ & 0.000* \\
\hline $\begin{array}{l}\text { 24. There is disposal committee established for } \\
\text { totally damaged material. }\end{array}$ & $.599^{* *}$ & $0.000 *$ \\
\hline $\begin{array}{l}\text { 25. Continues follow up and motivation of all units } \\
\text { to immediately report materials to be disposed. }\end{array}$ & $.682^{* * *}$ & $0.001 *$ \\
\hline $\begin{array}{l}\text { 26. Different and appropriate disposal for } \\
\text { different obsolete materials. }\end{array}$ & $.758^{* * *}$ & $0.000 *$ \\
\hline $\begin{array}{l}\text { 27. All resources in our office are always } \\
\text { functional. }\end{array}$ & $.685^{* *}$ & $0.000 *$ \\
\hline $\begin{array}{l}\text { 28. My office materials are all as per my } \\
\text { specification. }\end{array}$ & $.653^{* *}$ & $0.000 *$ \\
\hline $\begin{array}{l}\text { 29. The quality of the purchased resource is as } \\
\text { requested. }\end{array}$ & $.714^{* * *}$ & $0.000 *$ \\
\hline $\begin{array}{l}\text { 30. There is a fast maintenance and replacement } \\
\text { of damaged materials }\end{array}$ & $.655^{* *}$ & $0.000 *$ \\
\hline
\end{tabular}




\begin{tabular}{|c|c|c|}
\hline $\begin{array}{l}\text {-5 Correlation coefficient between each state } \\
\text { performance" and the total score of the domai }\end{array}$ & nt of $t$ & \\
\hline Statements & $\begin{array}{c}\text { Pearson } \\
\text { correlation } \\
\text { coefficient }\end{array}$ & SIG \\
\hline $\begin{array}{l}\text { 1. The leaders nurture an organizational culture } \\
\text { focused on performance improvement. }\end{array}$ & $.782^{* *}$ & $0.000 *$ \\
\hline $\begin{array}{l}\text { 2. There is a commitment from high-level } \\
\text { leadership to implement performance } \\
\text { management practices. }\end{array}$ & $.824^{* * *}$ & $0.000 *$ \\
\hline $\begin{array}{l}\text { 3. There is assessing and evaluating for agency's } \\
\text { capacity to provide services based on } \\
\text { community needs. }\end{array}$ & $.801^{* * *}$ & $0.000 *$ \\
\hline $\begin{array}{l}\text { 4. Customer/stakeholder feedback is used to } \\
\text { make program decisions or system changes. }\end{array}$ & $.773^{* *}$ & $0.000 *$ \\
\hline $\begin{array}{l}\text { 5. There is someone responsible for integrating } \\
\text { performance management efforts across your } \\
\text { agency. }\end{array}$ & $.837^{* * *}$ & $0.000 *$ \\
\hline 6. Managers trained to manage performance. & $.832^{* *}$ & $0.001 *$ \\
\hline $\begin{array}{l}\text { 7. Managers involved in maintaining and } \\
\text { improving performance management } \\
\text { practices. }\end{array}$ & $.860^{* *}$ & $0.000 *$ \\
\hline $\begin{array}{l}\text { 8. The strategic plan is a part of the agency's } \\
\text { performance improvement strategies. }\end{array}$ & $.707^{* *}$ & $0.000 *$ \\
\hline $\begin{array}{l}\text { 9. Personnel and financial resources assigned to } \\
\text { sustain performance management functions. }\end{array}$ & $.675^{* *}$ & $0.000 *$ \\
\hline 10. Financial reward is more prefer. & $.415^{* * *}$ & $0.000 *$ \\
\hline 11. Non-financial reward is more prefer. & $.486^{* *}$ & $0.000 *$ \\
\hline
\end{tabular}

\section{Reliability of the Questionnaire}

Split half test was used to check the reliability of the questionnaire according to the responses of the 82 participants. Table (2) shows the results of the test, where the values of Split half for all variables of the study and for the instrument as a whole are highly acceptable in research 
and humanitarian studies; it was 0.866 for budget, 0.890 for human resources, 0. 842 for material resources, 0.895 for resources' allocation, 0.891 for total resources, and 0.846 for hospital performance.

Table (3.2) Reliability

\begin{tabular}{|l|l|c|c|}
\hline No & \multicolumn{1}{|c|}{ Variables } & No of items & Split half \\
\hline 1 & Budget & 12 & 0.866 \\
\hline 2 & Human resources & 9 & 0.890 \\
\hline 3 & Material resources & 10 & 0.842 \\
\hline 4 & Resources' allocation & 11 & 0.895 \\
\hline 5 & Total resources & 30 & 0.891 \\
\hline 6 & Hospital performance & 11 & 0.846 \\
\hline
\end{tabular}

\section{Response Rate:}

Table (3.3) shows that the research population is consisted of (86) administrators. The number of respondents is correct $.94 .2 \%$, the number of excluded due to not response $5.8 \%$.

Table (3.3) Response rate

\begin{tabular}{|l|l|l|}
\hline & $\mathrm{N}$ & $\%$ \\
\hline Response & $\mathbf{8 1}$ & $\mathbf{9 4 . 2}$ \\
\hline Not response & 5 & $\mathbf{5 . 8}$ \\
\hline Population & $\mathbf{8 6}$ & $\mathbf{1 0 0 . 0 0}$ \\
\hline
\end{tabular}

\section{Data Entry and Analysis:}

Data entry and analysis will accomplish using the Statistical Package for the Social Sciences (SPSS) statistical program version 22. For categorical variables (frequencies and percentages) was used. While for numeric variables (mean and standard deviation) was for description .Chi- 
square was used. P-value of less than 0.05 was considered statistically significant.

\section{Limitation:}

Subjective: This study focused only on two economic factors (Budget \&resources) affecting healthcare performance.

Time: This study was conducted from 2017-2018 (one year)

Location: This study included the directors, heads of departments and head nurses who worked in Security Forces Hospital in Makkah.

Time Line:

\begin{tabular}{|l|l|}
\hline Proposal & October 2017 \\
\hline Ethical approval obtaining & November 2017 \\
\hline Questionnaire distribution & January 2018 \\
\hline Statistical analysis & February 2018 \\
\hline Writing discussion & March 2018 \\
\hline
\end{tabular}




\section{Chapter Four:Data Analysis and Results Discussion}

\section{Preface}

This chapter discussed the analysis of the collected data, description of the population, description of the study tool and the results of hypotheses testing.

\section{Statistical analysis:}

To answer the research's questions and test the hypothesis, several statistics methods were used:

Descriptive statistics is used in order to describe the characteristics of the variables, the study used (number \& frequency and mean \pm SD).

Analytic statistics is used in order to detect the relation, Chi square was used. $\mathrm{P}$ value $<0.05$ considered statistically significant.

\section{Demographic data:}

This section presents the demographic data of participants that includes gender, age, position, and experience. This study included 81 participants of which 61(75.3\%) were male and 20 (24.7\%) were female. Regarding the age the data shows 36 (44.4\%) were from group age 40- less than 50 years, $38.3 \%$ is 30 to less than $40,13.6 \%$ is 50 to less than 60 , and $3.7 \%$ is less than 30 . While, the position data shows third $(30.9 \%)$ were directors, $27.2 \%$ were from nursing department, $22.2 \%$ were head of administration department, and $19.8 \%$ were head of medical department. The experience data of participants shows (34.6\%) were from group (15 years' experience and more), and the second third (33.3\%) were from group (10- less than 15 years' experience), 25 (30.9\%) were from group (5less than 10 years). 
Table (4-1) demographic data

\begin{tabular}{|l|l|c|c|}
\hline Variables & \multicolumn{1}{|c|}{ Categories } & N & $\%$ \\
\hline \multirow{3}{*}{ Gender } & male & 61 & 75.3 \\
\cline { 2 - 4 } & female & 20 & 24.7 \\
\hline \multirow{4}{*}{ Age } & less than 30 years & 3 & 3.7 \\
\cline { 2 - 4 } & 30- less than 40 years & 31 & 38.3 \\
\cline { 2 - 4 } & 40- less than 50 years & 36 & 44.4 \\
\cline { 2 - 4 } & 50- less than 60 years & 11 & 13.6 \\
\hline \multirow{4}{*}{ Position } & Head of administration department & 18 & 22.2 \\
\cline { 2 - 4 } & Head of medical department & 16 & 19.8 \\
\cline { 2 - 4 } & Director & 25 & 30.9 \\
\cline { 2 - 4 } & Nursing department & 22 & 27.2 \\
\hline \multirow{3}{*}{ Experience } & less than 5 years & 1 & 1.2 \\
\cline { 2 - 4 } & 5- less than 10 years & 25 & 30.9 \\
\cline { 2 - 4 } & 10- less than 15 years & 28 & 33.3 \\
\cline { 2 - 4 } & 15 years and more & 34.6 \\
\hline
\end{tabular}

The majority of the items $83.3 \%$ (10 items) $(1,2,3,5,6,7,8,10,11 \& 12)$ had high mean score between (3.6-4), where the highest score was for item1 (Management participate in assessing annual budget needs) with mean score 4, following by item 3 (Estimates of needs are decided by departments taken in consideration when preparing the budget) with mean score 3.9. While 2 items 16.7\% (4\&9) (Are you notified of the amounts approved for you in the annual budget?)\&(The approved amounts to be used in what they actually planned.) had moderate mean between (3.3-3.5. All items showed significant difference $(p<0.05)$, indicating high degree of agreement on budget variable. 
Table (4-2) The budget:

\begin{tabular}{|c|c|c|c|c|c|}
\hline Statement & Mean & SD & DF & $\mathbf{X}^{2}$ & P value \\
\hline $\begin{array}{l}\text { 1. Management participate in assessing } \\
\text { annual budget needs }\end{array}$ & 4 & 0.9 & 4 & 70.0 & $0.0001 * *$ \\
\hline $\begin{array}{l}\text { 2. There are models for presenting the } \\
\text { annual estimated management } \\
\text { requirement }\end{array}$ & 3.7 & 0.8 & 4 & 80.5 & $0.0001 * *$ \\
\hline $\begin{array}{l}\text { 3. Estimates of needs are decided by } \\
\text { departments taken in consideration } \\
\text { when preparing the budget }\end{array}$ & 3.9 & 0.9 & 4 & 46.3 & $0.0001 * * *$ \\
\hline $\begin{array}{l}\text { 4. Are you notified of the amounts } \\
\text { approved for you in the annual budget? }\end{array}$ & 3.3 & 1.2 & 4 & 10.4 & $0.034 *$ \\
\hline $\begin{array}{l}\text { 5. The amounts approved in the budget } \\
\text { help to provide services efficiently. }\end{array}$ & 3.8 & 0.9 & 4 & 37.7 & 0.0001*** \\
\hline $\begin{array}{l}\text { 6. The budget manages the resolution of } \\
\text { emergency crises that may occur } \\
\text { during the financial year and beyond } \\
\text { the estimates. }\end{array}$ & 3.8 & 0.9 & 4 & $\mathbf{5 7 . 5}$ & 000 \\
\hline $\begin{array}{l}\text { 7. There is flexibility in budget management } \\
\text { to adjust the estimation errors. }\end{array}$ & 3.7 & 0.9 & 4 & 54.1 & $0.0001 * *$ \\
\hline $\begin{array}{l}\text { 8. The amounts allocated to the } \\
\text { departments divided according to } \\
\text { actual need. }\end{array}$ & 3.7 & 0.8 & 4 & 66.8 & $0.0001 * *$ \\
\hline $\begin{array}{l}\text { 9. The approved amounts to be used in } \\
\text { what they actually planned. }\end{array}$ & 3.5 & 0.9 & 4 & 45.1 & $0.0001 * *$ \\
\hline $\begin{array}{l}\text { 10. During the implementation stages of } \\
\text { the budget, there is a monitor the plans } \\
\text { that are prepared by you in } \\
\text { partnership with others (budget, } \\
\text { follow-up, planning). }\end{array}$ & 3.7 & 0.9 & 4 & 57.2 & $0.0001 * *$ \\
\hline $\begin{array}{l}\text { 11. The comparison between what was } \\
\text { approved and what was requested done } \\
\text { at the end of the financial year, and } \\
\text { specifying the deficiencies and } \\
\text { insufficiency. }\end{array}$ & 3.7 & 0.9 & 4 & 48.9 & $0.0001 * *$ \\
\hline $\begin{array}{l}\text { 12. The board has one or more members } \\
\text { with professional-level financial } \\
\text { expertise. }\end{array}$ & 3.8 & 0.9 & 4 & 42.6 & $0.0001 * *$ \\
\hline Total budget score & 3.71 & 0.6 & 27 & 39.6 & 0.06 \\
\hline
\end{tabular}


The majority of the items $88.9 \%$ ( 8 items) $(1,2,3,4,5,6,7 \& 8)$ had high mean score between 3.7-3.9, where the highest means score was for item (The organization encourages employees to suggest product/process improvement) with mean score 3.9. While one item 11.1\% (9) (There is enough man power in the department) had moderate mean score 3.2. All items showed significant difference $(\mathrm{p}<0.05)$, indicating high degree of agreement on human resources variable.

Table (4-3) Human Recourses:

\begin{tabular}{|c|c|c|c|c|c|}
\hline Statement & Mean & SD & DF & $\mathbf{X}^{2}$ & P value \\
\hline $\begin{array}{l}\text { Organization's HR executives are fully } \\
\text { aware of the business needs and } \\
\text { strategies. }\end{array}$ & 3.8 & 0.7 & 3 & 32.8 & $0.0001 * *$ \\
\hline $\begin{array}{l}\text { All major jobs are subject to formal job } \\
\text { analysis. }\end{array}$ & 3.7 & 0.8 & 3 & 21.9 & $0.0001 * *$ \\
\hline $\begin{array}{l}\text { The organization has a formal policy of } \\
\text { career planning and development. }\end{array}$ & 3.8 & 1. & 4 & 38.2 & $0.0001 * *$ \\
\hline $\begin{array}{l}\text { The organization follows a formal } \\
\text { procedure of potential appraisal. }\end{array}$ & 3.8 & 0.8 & 3 & 30.6 & $0.0001 * *$ \\
\hline $\begin{array}{l}\text { The organization has a structured policy } \\
\text { for management of attrition and } \\
\text { turnover. }\end{array}$ & 3.8 & 1.0 & 4 & 30.1 & $0.0001 * *$ \\
\hline $\begin{array}{l}\text { The organization encourages employees } \\
\text { to suggest product/process improvement. }\end{array}$ & 3.9 & 0.9 & 3 & 19.5 & $0.0001 * *$ \\
\hline $\begin{array}{l}\text { The organization has provision for } \\
\text { employee recognition programs and } \\
\text { awards. }\end{array}$ & 3.7 & 0.9 & 4 & 46.8 & $0.0001 * *$ \\
\hline $\begin{array}{l}\text { The organization has been managing } \\
\text { change by integrating the HR issues with } \\
\text { the business strategies and the strategic } \\
\text { change process. }\end{array}$ & 3.7 & 0.9 & 4 & 35.7 & $0.0001 * *$ \\
\hline $\begin{array}{l}\text { There is enough man power in the } \\
\text { department. }\end{array}$ & 3.2 & 1.0 & 4 & 13.4 & $0.0001 * *$ \\
\hline Total human resources score & 3.71 & 0.7 & 21 & 25.7 & 0.22 \\
\hline
\end{tabular}


More than half of the items $60 \%$ (6 items) $(3,4,5,8,9, \& 10)$ had moderate mean score between 3.0-3.5. While four items $40 \%(1,2,6 \& 7)$ had high mean score between 3.6-3.9. The highest mean score was for item 1 (There is need assessment for material resources in my organization) with mean score 3.9, followed by item 2 (There is Planning of purchasing material resources in my section) with mean score 3.8,then item 7(The hospital follows WHO recommendation in storing equipment) with mean score 3.7, and item 6(Stores are secured enough) with mean score 3.6. All items showed significant difference $(p<0.05)$, indicating moderate degree of agreement on material resources variable.

Table (4-4) Material Recourses:

\begin{tabular}{|l|l|l|l|l|l|}
\hline Variables & Mean & SD & DF & X2 & P value \\
\hline $\begin{array}{l}\text { There is need assessment for material } \\
\text { resources in my organization. }\end{array}$ & 3.9 & 0.7 & 3 & 47.8 & $\mathbf{0 . 0 0 0 1 * *}$ \\
\hline $\begin{array}{l}\text { There is Planning of purchasing material } \\
\text { resources in my section. }\end{array}$ & 3.8 & 0.9 & 4 & 47.1 & $\mathbf{0 . 0 0 0 1 * *}$ \\
\hline $\begin{array}{l}\text { There is a quick and reliable selection for } \\
\text { the suppliers. }\end{array}$ & 3.3 & 1.0 & 4 & 21.2 & $\mathbf{0 . 0 0 0 1 * *}$ \\
\hline $\begin{array}{l}\text { Sufficient permanent stores are built in } \\
\text { the organization. }\end{array}$ & 3.2 & 1.0 & 4 & 19.7 & $\mathbf{0 . 0 0 0 1 * *}$ \\
\hline Sufficient material resources were stored. & 3.1 & 1.0 & 4 & 16.3 & $\mathbf{0 . 0 1 *}$ \\
\hline $\begin{array}{l}\text { The hospital follows WHO } \\
\text { recommendation in storing equipment. }\end{array}$ & 3.6 & 1.0 & 4 & 28.9 & $\mathbf{0 . 0 0 0 1 * *}$ \\
\hline
\end{tabular}

\begin{tabular}{|l|l|l|l|l|l|}
\hline Stores are secured enough. & 3.7 & 0.9 & 4 & 39.8 & $0.0001^{* *}$ \\
\hline $\begin{array}{l}\text { The material resource in my office have } \\
\text { audited annually. }\end{array}$ & 3.2 & 1.0 & 4 & 19.8 & $0.001^{*}$ \\
\hline $\begin{array}{l}\text { Follow up of material resource is done } \\
\text { quarterly, semiannually and annually by } \\
\text { property administration department. }\end{array}$ & 3.4 & 1.0 & 4 & 24.3 & $0.0001^{* *}$ \\
\hline $\begin{array}{l}\text { Identify the level of damage and } \\
\text { depreciation of each material. }\end{array}$ & 3.5 & 0.9 & 4 & 46.3 & $0.0001^{* *}$ \\
\hline Total material resources score & 3.51 & 0.7 & 24 & 34.7 & 0.07 \\
\hline
\end{tabular}


The majority of the items $91 \%$ (10 items) $(1,2,3,4,5,6,7,8,9 \& 10)$ had high mean score between 3.6-3.9, where the highest mean score was for items 1 and 2 (1. Allocate adequate budget for maintenance.)\&(2. Use of qualified personnel for maintenance.) with mean score 3.9. While one item 9\% (11) (There is a fast maintenance and replacement of damaged materials) had moderate mean score 3.5. All items showed significant difference $(\mathrm{p}<0.05)$, indicating high degree of agreement on resources allocation variable.

Table (4-5) Recourses Allocation:

\begin{tabular}{|l|l|l|l|l|l|}
\hline Variables & Mean & SD & DF & X2 & P value \\
\hline $\begin{array}{l}\text { Allocate adequate budget for } \\
\text { maintenance. }\end{array}$ & 3.9 & 0.8 & 3 & 29.1 & $0.0001^{* *}$ \\
\hline $\begin{array}{l}\text { Use of qualified personnel for } \\
\text { maintenance. }\end{array}$ & 3.9 & 0.9 & 3 & 25.6 & $\mathbf{0 . 0 0 0 1}$ 1** $^{* *}$ \\
\hline $\begin{array}{l}\text { Redistribution of the maintained } \\
\text { materials. }\end{array}$ & 3.8 & 0.9 & 3 & 18.4 & $\mathbf{0 . 0 0 0 1}^{* *}$ \\
\hline $\begin{array}{l}\text { Regular and efficient Identification of } \\
\text { obsolete materials. }\end{array}$ & 3.7 & 0.9 & 3 & 22.7 & $\mathbf{0 . 0 0 0 1}^{* *}$ \\
\hline $\begin{array}{l}\text { There is disposal committee established } \\
\text { for totally damaged material. }\end{array}$ & 3.7 & 1.0 & 3 & 32.7 & $\mathbf{0 . 0 0 0 1} * *$ \\
\hline
\end{tabular}

\begin{tabular}{|l|l|l|l|l|l|}
\hline $\begin{array}{l}\text { Continues follow up and motivation of } \\
\text { all units to immediately report materials } \\
\text { to be disposed. }\end{array}$ & 3.7 & 0.9 & 4 & 19.9 & $0.0001^{* *}$ \\
\hline $\begin{array}{l}\text { Different and appropriate disposal for } \\
\text { different obsolete materials. }\end{array}$ & 3.7 & 0.8 & 3 & 32.1 & $0.0001^{* *}$ \\
\hline $\begin{array}{l}\text { All resources in our office are always } \\
\text { functional. }\end{array}$ & 3.7 & 0.8 & 3 & 62.4 & $0.0001^{* *}$ \\
\hline $\begin{array}{l}\text { My office materials are all as per my } \\
\text { specification. }\end{array}$ & 3.8 & 0.9 & 4 & 49.5 & $0.0001^{* *}$ \\
\hline $\begin{array}{l}\text { The quality of the purchased resource is } \\
\text { as requested. }\end{array}$ & 3.7 & 0.9 & 4 & 42.9 & $0.0001^{* *}$ \\
\hline $\begin{array}{l}\text { There is a fast maintenance and } \\
\text { replacement of damaged materials }\end{array}$ & 3.5 & 0.9 & 4 & 58.2 & $0.0001^{* *}$ \\
\hline Total allocation resources score & 3.73 & 0.6 & 23 & 25.96 & 0.03 \\
\hline
\end{tabular}


The majority of the items $82 \%$ (9 items) $(1,2,3,4,5,7,8,9 \& 10)$ had high mean score between 3.7-3.9, where the highest mean score was for items $(1 \& 2)$ (The leaders nurture an organizational culture focused on performance improvement.) \& (There is a commitment from high-level leadership to implement performance management practices.) with mean score 3.9. Whiletow items 18\% (6\&11) had moderate mean score between 3.3-3.5. All items showed significant difference $(p<0.05)$, indicating high degree of agreement on hospital performance variable.

Table (4-6) Hospital performance:

\begin{tabular}{|l|l|l|l|l|l|}
\hline variables & Mean & SD & DF & X2 & P value \\
\hline $\begin{array}{l}\text { 1.The leaders nurture an organizational } \\
\text { culture focused on performance } \\
\text { improvement. }\end{array}$ & 3.9 & 0.9 & 4 & 56.9 & $\mathbf{0 . 0 0 0 1 * *}$ \\
\hline $\begin{array}{l}\text { 2.There is a commitment from high- } \\
\text { level leadership to implement } \\
\text { performance management practices. }\end{array}$ & 3.9 & 0.9 & 3 & 13.9 & $\mathbf{0 . 0 0 3 *}$ \\
\hline
\end{tabular}

\begin{tabular}{|l|l|l|l|l|l|}
\hline $\begin{array}{l}\text { 3.There is assessing and evaluating for } \\
\text { agency's capacity to provide services } \\
\text { based on community needs. }\end{array}$ & 3.7 & 0.9 & 3 & 22.4 & $0.0001 * *$ \\
\hline $\begin{array}{l}\text { 4.Customer/stakeholder feedback is } \\
\text { used to make program decisions or } \\
\text { system changes. }\end{array}$ & 3.7 & 0.9 & 4 & 46.8 & $0.0001 * *$ \\
\hline $\begin{array}{l}\text { 5.There is someone responsible for } \\
\text { integrating performance management } \\
\text { efforts across your agency. }\end{array}$ & 3.7 & 1.0 & 4 & 44.7 & $0.0001 * *$ \\
\hline $\begin{array}{l}\text { 6.Managers trained to manage } \\
\text { performance. }\end{array}$ & 3.5 & 1.0 & 4 & 28.9 & $0.0001 * *$ \\
\hline $\begin{array}{l}\text { 7.Managers involved in maintaining } \\
\text { and improving performance } \\
\text { management practices. }\end{array}$ & 3.7 & 1.0 & 4 & 45.4 & $0.0001 * *$ \\
\hline $\begin{array}{l}\text { 8.The strategic plan is a part of the } \\
\text { agency's performance improvement } \\
\text { strategies. }\end{array}$ & 3.8 & 0.8 & 3 & 24.7 & $0.0001 * *$ \\
\hline $\begin{array}{l}\text { 9.Personnel and financial resources } \\
\text { assigned to sustain performance } \\
\text { management functions. }\end{array}$ & 3.8 & 0.8 & 3 & 30.5 & $0.0001 * *$ \\
\hline
\end{tabular}




\begin{tabular}{|l|l|l|l|l|l|}
\hline 10.Financial reward is more prefer. & 3.7 & 1.0 & 4 & 32.6 & $\mathbf{0 . 0 0 0 1} * *$ \\
\hline 11.Non-financial reward is more prefer. & 3.3 & 1.0 & 4 & 35.4 & 0.0001 \\
Total hospital performance score & 3.70 & 0.7 & 27 & 30.65 & $\mathbf{0 . 2 7}$ \\
\hline
\end{tabular}

\section{Research Hypotheses testing:}

Table (4-7) showed a significant relationship between budget and hospital performance, where $\mathrm{X}^{2}=20.796$ and P-value $<0.0001$. Poor budget lead to poor hospital performance and vice versa. Also, showed a significant relationship between human resources and hospital performance where $X^{2}=36.260$ and $P$-value $<0.0001$. Poor human resources lead to poor hospital performance and vice versa. It showed a significant relationship between material resources and hospital performance, where $X^{2}=30.524$ and P-value $<0.0001$. Poor material resources lead to poor hospital performance and vice versa. And showed a significant relationship between resources allocation and hospital performance, where X2=29.966 and Pvalue $<0.0001$. Poor resources allocation lead to poor hospital performance and vice versa.

Table (4-7) The relation between hospital performance and budget, human resources, material resources, and resources allocation

\begin{tabular}{|l|l|l|l|l|l|}
\hline & \multicolumn{6}{|l|}{ Hospital performance } & \multicolumn{2}{l|}{} \\
\cline { 2 - 7 } & Mean & SD & DF & X2 & P-value \\
\hline Budget & 3.71 & 0.6 & 27 & 20.796 & $<0.0001 *$ \\
\hline Human recourses & 3.71 & 0.7 & 21 & 36.260 & $<0.0001 *$ \\
\hline Material resources & 3.51 & 0.7 & 24 & 30.524 & $<0.0001 *$ \\
\hline $\begin{array}{l}\text { Resources } \\
\text { allocation }\end{array}$ & 3.73 & 0.6 & 23 & 29.966 & $<0.0001 *$ \\
\hline
\end{tabular}

\section{Discussion}

This section is focused on discussing the key findings related to the objectives of the whole study.

The aim of this study was to identify the effect of economic factors (budget, and resources) on healthcare performance in Security Forces 
Hospital-Makkah. In order to help in increasing the experience and knowledge of weakness and strength areas to improve the performance and professional growth.

The main findings of the study revealed that economic factors (budget and resources) have an essential influence on hospital performance which affects the whole vision of the performance.

This finding consistent with the findings of the reviewed studies in chapter II such as Libby and Lindsay (2009), and King R (2010) for budget. Baghbanian (2011), and Smith (2016) for resources.

Regarding the hypothesis one, the results showed a significant relation between budget and hospital performance, where X2=20.796 and $\mathrm{P}$-value $<0.0001$. Which means that budget and budgetary have a great role and influence on the hospital performance. This finding consistent with Libby and Lindsay (2009) study, where they reported that budget stillUsing for control purposes and are perceived to be value-added(Libby and Lindsay ,2009).Also, in 2007 study, the author presented the increasingly expensive sector as "wired for control" and budgeting systems as "traffic lights" (Byrne,2007).

Regarding the hypothesis two, the results showed a significant relation between human recourses and hospital performance, where $\mathrm{X} 2=36.260$ and $\mathrm{P}$-value $<0.0001$. Which means that human recourses have a great role and influence on the hospital performance. This finding consistent with Harris study (2007), where the author reported relationships between a range of HRM practices, policies systems and organization performance(Harris C, 2007).

Regarding the hypothesis three, the results showed a significant 
relation between material recourses and hospital performance, where $\mathrm{X} 2=30.524$ and $\mathrm{P}$-value $<0.0001$. Which means that material recourses have a great role and influence on the hospital performance. This consistent with Kim (2015) study, where the authors reported that controlling material resources increased the level of performance(Kim et al, 2015).Also, it consistent with Ragupathi study (2013), where the author reported the relation between financial resources and hospital performance

\section{(Ragupathi,2013)}

Regarding the hypothesis four, the results showed a significant relation between recourses allocation and hospital performance, where $\mathrm{X} 2=29.966$ and $\mathrm{P}$-value $<0.0001$. Which means that recourses allocation has a great role and influence on the hospital performance. This finding consistent with Smith (2016) study, where they designed a framework to help decision makers in healthcare to assess their practice, identify key areas for improvement, decide how to allocate resources in order to provide good quality of care (Smith,2016). Another study reported that decision makers had several reasons influence their decision in allocating resources, also they reported that the political and bureaucratic structures had great influence on the decision (Hasman et al, 2008).

The current study differs from some other studies such as that of Horn by and Forte (2010), which aimed to examine the use of human resource indicators (HRI) to support management-led initiatives to improve health service efficiency and effectiveness, however, the current study aimed to detect the relation between human resources and hospital performance. In addition, the current study differs from Macinati (2014), where the reviewed study focused on analyzing the motivational role of budgetary participation and the intervening goal of individuals' mental states and behaviors in influencing the relationship between budgetary 
participation and performance., while the current one aimed to the relation between budget and hospital performance (Macinati ,2014).

\section{Chapter Five: Summary, Conclusion \& Recommendation}

\section{Preface}

This chapter included a summary of the study, the conclusion of the study is, following by the recommendations for future research directions.

\section{Summary:}

Chapter one covered the research background, problem and significance of the study, objectives, methodology and research structure, the research model, and the hypotheses were developed to examine the relation between hospital performance and budget, human resources, material resources, and resources allocation in the Security Forces Hospital, Makkah, Saudi Arabia during 2018., where the main objective of this study was to identify the effect of two economics factors which are budget, resources, on hospital performance.

Chapter two reviewed the previous studies detecting the relation between hospital performance and budget, human resources, material resources, and resources allocation,

Chapter three focused on the research design and the selection of appropriate research methods to examine the research model. Additionally, it covered a description of the population, and how the data is accessed and collected. The questionnaire development, data analysis techniques, construct validity and overall reliability are estimated followed by ethical approval, where the researcher used the descriptive 
analytic approach, using a questionnaire to collect the data from 86workers in administration positions in the Security Forces Hospital.

Chapter four introduced the data analysis starting with descriptive data analysis for the demographic factors followed by testing the research hypotheses using Chi square analysis and discussion of the findings. As well as discussed the finding of the study, where the findings of the Chi square analysis confirmed significant relation between hospital performance and budget, human resources, material resources, and resources allocation,

Chapter five provided summary, conclusion, and recommendations of the current research findings, where the researcher concluded that there is a relationship between hospital performance and economics factors , and recommended further studies.

\section{Conclusion:}

Based on the findings, the researcher concluded the following:

Budget has an important influence on hospital performance. As a result, organizations should take care of budgetary strategies and process.

Human resources have an important influence on hospital performance. As a result, organizations should take care of providing medical and nonmedical staff by the appropriate training.

Material resources has an important influence on hospital performance. As a result, organizations should take care of providing the facility with all necessary equipment, so the quality of care will be raise up.

Resource allocation has an important influence on hospital performance. As a result, organizations should take care of resource allocation priorities and setting. 


\subsection{Recommendations of the Study:}

Based on the study findings, the researcher recommended the following:

- The organization (hospital) should take care and work hardly on the budgetary strategies and process.

- The organization (hospital) should take care and provide the staff with training opportunities to increase the quality of service.

- The organization (hospital) should take care and provide the facility with all necessary equipment to increase the quality of service.

- The organization (hospital) should take care and provide the stockholder and administrator with the appropriate training on the new methods and techniques of managing resources and how to allocate them.

- Further studies need to be conducted to detect the influence of others economic factors on the organization performance, and further multicenter studies need to be conducted to detect the influence of economic factors on the organization performance. 


\section{REFERENCES}

1. Almalki M, Fitzgerald G, Clark M. Health care system in Saudi Arabia: an overview. East Mediterr Health J. 2011 Oct;17(10):784-93.

2. Almutairi KM, Moussa M. Systematic review of quality of care in Saudi Arabia. A forecast of a high-quality health care. Saudi Med J. 2014 Aug;35(8):802-9.

3. Baghbanian $\mathrm{A}^{\mathbf{1}}$, Hughes $\mathrm{I}, \underline{\text { Khavarpour FA.Resource allocation and }}$ economic evaluation in Australia's healthcare system. Aust Health Rev. 2011 Aug;35(3):278-83. doi: 10.1071/AH10890.

4. Banerjee A and Chaudhury s. Statistics without tears: Populations and samples. Ind Psychiatry J. 2010 Jan-Jun; 19(1): 60-65.

5. Basu S, Andrews J, Kishore S, Panjabi R, Stuckler D (2012) Comparative Performance of Private and Public Healthcare Systems in Low- and Middle- Income Countries: A Systematic Review. PLoS Med 9(6): e1001244. doi:10.1371/journal.pmed.1001244

6. Byrne, M. (2007a). The usefulness of budgets in the Healthcare sector, Irish Journal of Management, 27(2), 67- 73.

7. Danon-Hersch, N, Paccaud, F. Future trends in human resources for health care : a scenario analysis. 2005 Report

8. Drouin, J.P., Hediger, V., Henke, N., Kanzler, L., Leydon, E.F., \& De Santis, P. The health care century. Health International.2008. 7, 6-17.

9. Green A, (1992) An Introduction to Health Planning in Developing Countries, Oxford UniversityPress.UK

10. Gugushvili A, (2007) The advantages and disadvtages of needs based resource allocation in integrated health systems and market systems of health care provider reimbursement, MPRA Paper Number 3354, munich Personal RePEc Archive, University of Edinburgh, Scotland 
11. Haas, J and Gajdošová, E. (2016). The Performance Indicators for the State Health-related Expenditures: Lessons from OECD, Public finance in the Czech Republic and the EU registered by IGA VŠE under the registration number F1/1/2016.

12. Harris C, Cortvriend P, Hyde P, (2007) "Human resource management and performance in healthcare organisations", Journal of Health Organization and Management, Vol. 21 Issue: 4/5, pp.448-459, https://doi.org/10.1108/14777260710778961

13. Hasman A, McIntosh E, Hope T. What reasons do those with practical experience use in deciding on priorities for healthcare resources? A qualitative study. J Med Ethics. 2008 Sep;34(9):658-63. doi: 10.1136/jme.2007.023366.

14. Hornby P, Forte P. Human Resource Indicators and Health Service Performance Human Resources Development Journal.2003. 2(1)

15. Iacob Cand Constantin C. Budget - a perfect tool for performance evaluation health system?Munich Personal RePEc Archive. 2015

16. Isaiah SU. Human Resource Management and Organizational Achievement. Degree Thesis International Business.2012. https://www.theseus.fi/bitstream/handle/10024/52155/Isaiah_Sunday.pdf ?sequence $=1 \&$ is Allowed $=y$

17. Kalinichenko O, Amado CAF, Santos SP. Performance Assessment in Primary Health Care: A Systematic Literature Review. CEFAGE-UE Working Paper.2013. https://pdfs.semanticscholar.org/342e/48deec7d6580f5b49f4078f264e3a1 3c51db.pdf

18. Kim H-S, Kim Y-H, Woo J-S, Hyun S-J . ( $\uparrow+10)$ An Analysis of Organizational Performance Based on Hospital Specialization Level and 
Strategy Type. PLoS ONE 10(7): e0132257. doi:10.1371/ journal.pone.0132257

19. King R, Clarkson $M C$ and Wallace $S$. Budgeting practices and performance in small healthcare businesses. Management Accounting Research 2010.21(1):40-55

20. Libby $T$ and Lindsay RM Beyond budgeting or budgeting reconsidered? A survey of North-American budgeting practice.Management Accounting Research. 2009. 22(1): 56-75

21. López-Casasnovas $G$ and Soley-Bori $M$. The Socioeconomic Determinants of Health: Economic Growth and Health in the OECD Countries during the Last Three Decades.Int. J Environ Res Public Health. 2014 Jan; 11(1): 815-829.

22. Macinati MS ${ }^{\mathbf{1}}$, Rizzo MG. Budget goal commitment, clinical managers' use of budget information and performance. Health Policy. 2014 Aug;117(2):228-38. doi: 10.1016/j.healthpol.2014.05.003. Epub 2014 May 28

23..Maryhofer, W. and Brewster, C. "European Human Resource Management Researching Developments over Time", The International Review of Management Studies(2005) . 16(1).

24. Mcintyre, D. Anselmi, L., (2012) Guidance on using needs based formulae and gap analysis in the equitable allocation of health care resources in East and Southern Africa Regional Network for Equity in Health in Southern.

25. Mosadeghrad Ali Mohammad. Factors influencing healthcare service quality. International Journal of Health Policy and Management.2014; 3(2): 77-89. 
26. Ragupathi D. The Financial and Human resource Management Strategies to Develop the Organisation.Research Journal of Management Sciences.2010. 2(10):6-9

27. State of New Jersey, department of health, 2018. https://web.doh.state.nj.us/apps2/hpr/usingpsi.aspx

28. Smith N, Mitton C, Hall W, Bryan S, Donaldson C, Peacock S, Gibson JL, Urquhart B. High performance in healthcare priority setting and resource allocation: A literature- and case study-based framework in the Canadian context. Soc Sci Med. 2016 Aug;162:185-92. doi: 10.1016/j.socscimed.2016.06.027. Epub 2016 Jun 21.

29. Shamu S. Literature Review on Needs Based Resource Allocation. Rebuild programme: 2013. http://www.tarsc.org/publications/documents/REBUILD\%20RA\%20Lit \%20Review\%20FINAL\% 20Dec2013.pdf

30. Walston S, Al-Harbi Y, Al-Omar B. The changing face of healthcare in Saudi Arabia.Ann Saudi Med. 2008 Jul-Aug;28(4):243-50.

31. White J. Budget-makers and health care systems. Health Policy. 2013 Oct;112(3):163-71. doi: 10.1016/j.healthpol.2013.07.024. Epub 2013 Aug 6.

32. World Health Organization: World Health Report. (2000). Health Systems: Improving Performance. Geneva.http://www.who.int/whr/2000/en/

33. World Health Organization: World Health Systems Strengthening Glossary, 2017 http://www.who.int/healthsystems/hss_glossary/en/index5.html

34.Zikmund WG. Research Methods: Basic Data Analysis: Descriptive Statistics.2003. Health Economics Research Method 35. (http://www.businessdictionary.com). 